Synthesis, part of a Special Feature on Transitions, Resilience and Governance: Linking Technological, Ecological and Political Systems

\title{
The Politics of Reflexive Governance: Challenges for Designing Adaptive Management and Transition Management
}

\author{
$\underline{\text { Jan-Peter Voß }}^{1}$ and Basil Bornemann ${ }^{2}$
}

\begin{abstract}
New concepts of governance take account of ambivalence, uncertainty, and distributed power in societal change. They aim for reflexivity regarding the limits of prognostic knowledge and actual control of complex processes of change. Adaptive management and transition management are two examples that evolved from the analysis of social-ecological and sociotechnical systems, respectively. Both feature strategies of collective experimentation and learning. In this paper, we ask how these two designs of reflexive governance consider politics. Based on a framework of different dimensions and levels of politics, we show that they are mainly concerned with problem solving by a focal process, but conflict and asymmetric power relations, as well as the embedding of processes within broader political contexts, are neglected. We suggest two routes for integrating politics into the design of reflexive governance: (1) recognize the politics of learning for sustainable development and develop safeguards against domination and capture by powerful actors, and (2) systematically consider the embedding of governance designs in political contexts and their ongoing dynamics for political fit.
\end{abstract}

Key Words: adaptive management; embedding in political context; governance design; politics; reflexive governance; societal learning; transition management

\section{INTRODUCTION}

The boundaries of what is considered the challenge of environmental governance have been increasingly expanding. Early approaches to environmental governance focused on land development and pollution and aimed at protecting nature and human beings from disturbing interventions. Later, societal production and consumption as well as technology were recognized as part of the problem; environmental governance was, thus, directed at shaping society and technology in order to maintain social-ecological systems. Most recently, the patterns and processes of governance itself have come to be identified as challenges in working toward sustainable development because they define the very capacities by which societies shape and transform themselves.

This recent turn does not merely indicate a further broadening of focus, but a shift in perspective. The recognition of governance as part of the problem structure eliminates the position of an external supervisor and navigator of social change. There is no longer an outside from where neutral diagnosis and sovereign intervention can proceed. Governing sustainable development thus becomes concerned with its own conditions, the making of its own knowledge, the developmental dynamics of its own practices, and its (often) unintended consequences (Rip 2006, Voß and Kemp 2006, Smith and Stirling 2007). This reflexive stance toward governance abandons the assumption of "one" adequate problem framing, "one" true prognosis of consequences, and "one" best way to go that could be identified in an objective manner from a neutral, supervisory outlook on the (social-ecological) system as a whole. Instead, it integrates a diversity of perspectives, expectations, and strategies in a complex understanding of societal change. It embraces the understanding that societal change results from a multiplicity of distributed efforts at shaping it; and it searches for ways to retain the multi-dimensionality of problems, the openness of 
futures, and the diversity of approaches in searching for ways to cope with challenges of sustainable development.

From different research traditions such as ecology (Holling 1978, Armitage et al. 2007a), technology and innovation studies (Kemp 1994, Elzen et al. 2004), and policy studies (Kenny and Meadowcroft 1999, Lafferty 2004, Voß et al. 2007), efforts have been made to work out the implications of this shift in perspective for the design of governance arrangements. These discussions have yielded a variety of new governance designs that feature some common threads: although acknowledging a fundamental ambivalence of goals, uncertainty of knowledge, and distribution of power, they all emphasize participation, experimentation, and collective learning as key elements of governance. As such, they have been grouped together under the heading of reflexive governance (Voß et al. 2006). Two specific designs of reflexive governance that are the focus of this paper are adaptive management (AM) and transition management (TM). Both terms, although using "management" to invoke earlier traditions of resource management and innovation management, represent specific policy-oriented discourses that focus on the conceptualization of particular processes of social regulation. As such, we describe them as designs for governance. From within both discourses, explicit references to the concept of reflexive governance have been made (Szendzimir et al. 2006, Kemp and Loorbach 2006).

Recently, concerns have arisen about the political implications of reflexive governance in general, and TM and AM in particular (Shove and Walker 2007, Armitage 2008, Kern and Smith 2008, Voß et al. 2009a, Smith and Stirling 2010). As empirical research into the practice of participation, experimentation, and collective learning has shown, reflexive governance designs interact with realworld political contexts that influence their functioning and impair their effectiveness (Lee 1993, McLain and Lee 1996, Walters 1997, Conley and Moote 2003, Hahn et al. 2006, Armitage et al. 2007b, Kemp et al. 2007b, Plummer and FitzGibbon 2007, Walters 2007, Allan and Stankey 2009, Kallis et al. 2009). Furthermore, there are concerns about the democratic legitimacy of reflexive governance designs pertaining to issues such as unclear links with institutions of representative democracy (Hendriks and Grin 2007, Hendriks 2009b, Kallis et al. 2009: 640), their potential to marginalize particular interests and social groups (Lebel et al. 2006, Fennell et al. 2008, Shilling et al. 2009), their implicit normativity (Shove and Walker 2007, Scrase and Smith 2009), and their tendency to stabilize and reproduce an incumbent (capitalist) political economy (Nadasdy 2003, 2007).

With this paper, we would like to contribute constructively to this critical discussion. We argue that the critical concerns reflect some general conceptual shortcomings of reflexive governance designs. Although they focus on complexities of social-ecological or social-technical systems and their dynamics, both AM and TM tend to block out the political dimension of these systems (Smith and Stirling 2010) and, thus, do not adequately reflect the implications of politics for participation, experimentation, and collective learning. As others have noted before us, however, it is necessary to consider politics as a constitutive element of reflexive governance and to reflect carefully how it may play out in specific designs for participatory experimentation and learning.

As a first step in this direction, we offer an analytical framework that may help to create a clearer picture of how reflexive governance designs are embedded in and intertwined with politics. This framework can be applied to systematically unveil the political blind spots of reflexive governance designs and detect ways of addressing these potential shortcomings. It is meant to stimulate efforts for making reflexive governance designs politically more reflexive and the practice of reflexive governance more effective and legitimate.

\section{THE POLITICS OF REFLEXIVE GOVERNANCE-AN ANALYTICAL FRAMEWORK}

Decades of political research have brought about vast evidence about the manifold ways environmental governance is embedded in, entwined with, and shaped by politics. Here, we set out to condense some of these insights into an analytical framework that helps organize the reflection on politics in the design of reflexive governance. The framework is supposed to draw attention to the pervasiveness of politics as often unruly and hidden attempts at shaping the set-up, process, and outcome of governance to further beliefs and interests of particular actors. This shall serve as an heuristic device for mapping different forms of politics that are relevant when considering designs for new forms of governance. 
Table 1. Relevant aspects of politics in different dimensions and layers (examples)

\begin{tabular}{llll}
\hline \hline & & \multicolumn{1}{c}{ Dimensions } \\
\cline { 2 - 4 } Levels & $\begin{array}{l}\text { Policy } \\
\text { (problems and solutions) }\end{array}$ & $\begin{array}{l}\text { Polity } \\
\text { (rules and structure) }\end{array}$ & $\begin{array}{l}\text { Politics } \\
\text { (interaction and process) }\end{array}$ \\
\hline $\begin{array}{l}\text { Micro } \\
\text { (focal interaction) }\end{array}$ & $\begin{array}{l}\text { Problems and goals of a } \\
\text { specific governance process }\end{array}$ & $\begin{array}{l}\text { Rules of procedure for a } \\
\text { specific governance process }\end{array}$ & $\begin{array}{l}\text { Struggle for dominance } \\
\text { amg participants of a } \\
\text { governance process }\end{array}$ \\
$\begin{array}{l}\text { Meso } \\
\text { (policy domain) }\end{array}$ & $\begin{array}{l}\text { Problem definitions and } \\
\text { policy approaches that are } \\
\text { dominant within a policy } \\
\text { domain }\end{array}$ & $\begin{array}{l}\text { Institutional arrangements } \\
\text { within a policy domain }\end{array}$ & $\begin{array}{l}\text { Struggle of organized political } \\
\text { actors for dominant positions } \\
\text { within a policy domain }\end{array}$ \\
$\begin{array}{l}\text { Macro } \\
\text { (political system) }\end{array}$ & $\begin{array}{l}\text { Discourse of fundamental } \\
\text { political values and beliefs }\end{array}$ & $\begin{array}{l}\text { Constitutional rules and } \\
\text { political culture }\end{array}$ & $\begin{array}{l}\text { Struggle for dominance } \\
\text { among broad social groups, } \\
\text { sectors, classes, or regions }\end{array}$ \\
\hline
\end{tabular}

We refer to politics in a broad sense as the processing of a diversity ideas and interests with regard to public affairs. Politics comprise interactions and substantial accounts by which individual and collective actors struggle for the definition and the provision of the common good. It is through and within politics that power is gained and maintained, authority is assigned and executed, interests and ideas are articulated, conflicts arise and play out, collective action is organized, and public problems are defined, processed, and solved. Politics are thus constitutive for any form of governance.

For systematic inquiry into the politics of reflexive governance, we analytically distinguish between dimensions and levels of politics (Table 1). Whereas dimensions refer to a well-established distinction between different forms or "aggregate states" of politics, the notion of levels captures a layered structure of political contexts for any kind of focal interaction process.

With regard to dimensions, we differentiate between policy, polity, and politics proper (e.g., von Prittwitz 1994).

1. The policy dimension refers to substantial problems and solutions of politics. It includes the definition of policy problems as well as the formulation of reasoned proposals, strategies, and instruments to realize policy goals.

2. The polity dimension covers the structural side of politics. It comprises institutions, norms, and procedural settings, the "rules of the game" for ongoing political processes.

3. The dimension of "politics" proper denotes the actual process side of politics where individual and collective actors with diverging views and interests interact. Controversy over problems, solutions, and rules of the game and the struggle of actors to get their particular view established as the "common view" are relevant in this dimension.

With regard to levels, we distinguish among a focal process of immediate interactions (micro), the context of policy domains (meso), and the political system at large (macro) (cf. Kiser and Ostrom 1982, Rein and Schön 1993, Howlett 2009; compare also with Geels (2002) for levels of sociotechnical change). Above-mentioned dimensions of policy, polity, and politics can be identified at each of these levels. 
Fig. 1. Dimensions and layers of politics.

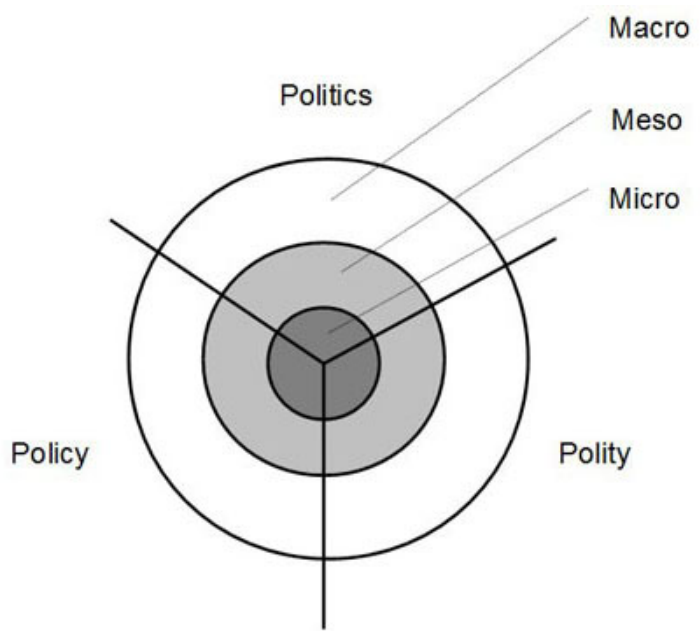

1. The micro level refers to a focal process of political interactions with a particular rule set (polity) that structures interactions among participating individuals (politics) who deal with specific problems and solutions (policy).

2. The meso level of politics includes patterns on the level of policy domains where comprehensive policy programs are negotiated that frame whole issue areas. This takes place in the context of issue-specific institutional arrangements (polity) that structure conflict and power struggle among organized collectives with stakes in a particular issue (politics).

3. The macro level captures broader patterns at the level of political systems that span a diversity of issue areas. It entails discourses about fundamental values and forms of political organization (policy), is structured by constitutional rules and basic cultural traditions (polity), and features political struggle along broad social cleavages, societal sectors, or classes (politics).

Putting dimensions and layers together into one framework, we gain a comprehensive schematic image of the politics that need to be considered when new forms of governance are designed (Fig. 1).

Coming back to the particular interest of this article, we suggest using this framework to organize critical inquiry into the politics of reflexive governance. First, we can reconstruct governance designs such as $\mathrm{AM}$ and TM with respect to their consideration of politics and identify blind spots regarding the political contexts in which they are embedded (next section). Second, we can use the framework to sketch directions for developing reflexive governance designs that are politically more robust.

\section{DESIGNS FOR REFLEXIVE GOVERNANCE, AND HOW THEY CONSIDER POLITICS}

\section{Adaptive Management}

Adaptive management is an approach to resource and ecosystem management that refers to functionally defined social-ecological systems with a regional scope, such as natural parks, river basins, mountain ranges, etc. (Walters 1986). With foundations in ecological systems theory and evolutionary theory (Holling 1978), AM has been postulated as a critical alternative to conventional rationalistic concepts of ecosystem management (Berkes et al. 2003a, Holling 2003). The literature pertaining to AM is quite diverse. Aside from theoretical contributions laying out the philosophical fundamentals of AM (Norton 1999, 2005), there is empirical research on the capabilities of governance arrangements to adaptively manage resilience (Berkes et al. 2003b; Lebel et al. 2006), as well as on the emergence of AM practices in various 
contexts (Olsson et al. 2004, 2006). Finally, a more prescriptive strand of literature that is at the focus of this article deploys guidelines and tools for setting up and implementing AM in practice (Sendzimir et al. 2006, Allan et al. 2009, see also www.adaptivem anagement.net/resources.php). Since it arose in the 1970s, the discourse has not yet yielded a singular notion of AM. Instead, we can observe a further conceptual differentiation as indicated by the emergence of approaches such as adaptive comanagement (ACM) and adaptive governance (AG) (Olsson et al. 2004, Brunner et al. 2005, Folke et al. 2005, 2009, Gunderson and Light 2006, Armitage et al. 2007a, 2009, Folke 2007, Kofinas 2009).

\section{Assumptions, conceptualization, and operationalization}

Adaptive management does not provide a blueprint for resource management, but rather some general ideas about social-ecological reality as well as conceptual suggestions of how to manage this reality. It rests on a set of distinct ontological assumptions condensed in "panarchy" (Gunderson and Holling 2002, Holling 2001), a general theory about the dynamics of complex social-ecological systems. According to panarchy, social-ecological systems exhibit unpredictable behavior and uncertainty that form the basic problem and "driving assumption underlying AM" (Sendzimir et al. 2006: 132). Given these fundamental problem features, classical approaches to resource management, which are based on models of linear dynamics or equilibrium and promote tight efforts to control, appear to be inadequate and ineffective (Berkes et al. 2003a). Following the proponents of AM, management rather has to establish and maintain the ability of social-ecological systems to adapt to complex and unpredictable change. Therefore, AM is conceptually concerned with learning, knowledge integration, and experimentation (Gunderson and Light 2006). First, AM is conceived of as an ongoing, structured, and reflexive learning process that allows for constant adaptation of the management practice to deal with the uncertainty of social-ecological development (Lee 1999, Sendzimir et al. 2006). Second, addressing the inherent complexity of these systems, AM puts particular emphasis on integrating various kinds of knowledge-scientific and professional as well as alternative forms of local and indigenous knowledge about social-ecological system behavior as well as management practices - to come up with a more comprehensive picture of the problems at hand (Berkes et al. 2003a). Third, the emphasis on learning and knowledge integration goes hand in hand with a focus on experimentation. Experiments are supposed to support knowledge acquisition and learning in order to explore the system's true structure (Sendzimir et al. 2006: 140, see McLain and Lee 1996). Moreover, policies themselves are conceptualized as hypotheses to be tested and constantly refined in practice (Berkes et al. 2003a), rendering $\mathrm{AM}$ an ongoing experiment for developing steering activities in which the policy maker becomes a "nimble experimenter, with the patience to consider long-term consequences" (Sendzimir et al. 2006: 132).

From a prescriptive perspective, these conceptual elements can be operationalized in terms of a structured learning cycle that links four phases integrating research, management, and practice (Sendzimir et al. 2006: 141, for an overview of descriptive process models; cf. Plummer 2009). The first phase is about improving the understanding of a given system by initiating discussion among the participants of an AM forum. The goal is to generate a balance of the known and the unknown that can serve as a basis for policy formulation in phase 2 . As policies, from an AM perspective, are fundamentally directed at "learning to adapt," they have to be designed in a flexible and reversible manner. Whereas the making of policies, accordingly, takes the form of designing and refining hypotheses, the implementation (phase 3 ) is conceived as a test of these hypotheses. Such a scientific approach is supposed to give policies a "disciplinary rigor of consistency in execution" (Sendzimir et al. 2006: 142) and prevent them from being changed during implementation. The fourth phase of the AM cycle entails the monitoring and evaluation of policy hypotheses in order to enable learning processes that improve the rationality of subsequent activities.

In sum, AM is based on an idea of learning by doing (Berkes et al. 2003a: 9, Kato and Ahern 2008), "learning by experimenting" (Lee 1999) or "learning while managing" (Sendzimir et al. 2006: 140). It suggests a notion of management that integrates science and local knowledge with experimental practices (Olsson et al. 2004, Gunderson and Light 2006) in an ongoing, recursive learning cycle in order to adapt to the uncertainty and surprise of complex, large-scale systems (Sendzimir et al. 2006). 


\section{Adaptive management and politics}

How does the conceptual literature on AM refer to politics and how can AM's notion of politics be contoured against the framework sketched out above? A general observation is that the discussion about AM does not make extensive use of a language that reflects political phenomena. Politics is certainly mentioned in early contributions (Lee 1993, 1999) and even more so in recent strands of ACM and AG, which, emphasizing the social dimension, show an expanded "political vocabulary" that refers to the political context and political success conditions of AM (Plummer 2009). However, the reflection of politics does not seem to be at the conceptual core of AM.

Nonetheless, politics does serve as an important reference point for AM. Initially, AM was articulated from a distinctly critical perspective on existing regimes of resource politics: as an approach directed at improving resource policy making by overcoming its modernist fallacies and political disruptions (see above). This shines through in various theoretical, normative, methodological, and practical features of AM.

On a theoretical level, AM conceives of the link between management and ecological resource systems in terms of a coevolutionary relationship facilitated by feedback loops (Berkes et al. 2003a). Concepts such as "feedback," "coevolution," "selforganization," and "resilience" suggest an ontology of integrated social-ecological systems that evolve quasi-automatically according to inner mechanisms of mutual structuring, but detached from political dynamics. Newer approaches of ACM and AG do in fact expand the scope of reflection on the management side of these systems to include a larger multi-layered governance structure (Folke et al. 2005, Folke 2007). However, they still build on AM's notion of systemic relationships to be managed, but not to be shaped politically.

This implies a particular normative claim regarding the purpose of governance: rather than politics-in the sense of, for example, political actors with values, interests, and ideas-it is the functional imperative to maintain the resilience of socialecological systems investigated by AM experts that is supposed to govern the world (Leach et al. 2007: 26-27). A claim that is, in fact, highly political because not only does it favor a particular goal of governance whose definition involves political value questions (Nadasdy 2007) but also a particular mode of managerial decision making, yet it disregards others (e.g., majority rules).

Methodologically, AM adopts a science-like approach to problem solving that involves the design, testing, and reformulation of hypotheses as elements of a more comprehensive cycle of learning that includes practical experimentation, the integration of different kinds of knowledge, as well as a variety of modeling techniques. Newer approaches embed this rather cognitive methodology in social practices characterized by concepts such as trust, vision, learning, collaboration, selforganization, creativity, innovation, power sharing, partnerships, etc. (Folke et al. 2005, Berkes 2007). Altogether, these design features render AM an effort at exploring the truth of resilience by the systematic acquisition and integration of knowledge through collaborative experimentation and learning.

Practical AM approaches, such as the one suggested by Sendzimir et al. (2006), aim at overcoming the "fundamental weaknesses of modern policy processes" (Sendzimir et al. 2006: 143) by excluding the political from working AM arrangements. Political items such as interests, opinions, and mandates are expected to be left outside of the AM forum due to their potential to provoke conflict, disturb cooperation, and thus foster irrationality. It is assumed that this can be achieved by selecting participants according to particular criteria such as competence, respect, and willingness to cooperate and by obliging them to "leave [their] gun[s] at the door" (Sendzimir et al. 2006: 142).

With respect to the framework outlined above, the AM design literature takes account of politics in a rather selective manner. The polity dimension is touched upon when organizational structures of AM arrangements such as "bridging organizations" and "shadow networks" are introduced. Likewise, basic procedural principles such as trust-based experimentation and collaborative learning are prescribed (Folke et al. 2005, Hahn et al. 2006). But aside from rather general references to the literature of institution building (Dietz et al. 2003), there are barely any further conceptual elaborations on specific designs of polity on the micro level (e.g., rules, sanctions, incentives, etc.) that in fact enable AM arrangements to function in accordance with these principles. Instead, some authors conceptualize 
the emergence of AM arrangements in terms of a process of spontaneous self-organization (see Berkes 2007: 25). A similar picture can be drawn with respect to the consideration of polity on the meso and macro levels. Although some newer contributions clearly acknowledge the embedding of AM in a multi-layered institutional context, it is not extensively reflected on how different institutional layers may impact on the structure, processes, and functions of an AM arrangement nor on how to design interfaces between $\mathrm{AM}$ and established forms of governance that enable the entire structure to work in an effective and legitimate way (Kallis et al. 2009).

Although there is some coverage of the polity dimension, conceptual reflections with respect to politics are scarce. Some authors, particularly those contributing to newer ACM and AG approaches, do mention the fundamental importance of political conflict due to differences in power and values as being inherent in environmental choices (Dietz et al. 2003). However, the implications for conceptualizing and designing AM are barely elaborated on. Regarding the micro level, forms of politics such as power struggles, tactics, and conflicts within an AM arrangement do not seem to play a considerable role. These "nasty politics" are practically excluded (e.g., by the requirement to leave guns at the door) or sidestepped by an optimistic language that highlights the "smooth" sides of knowledge production and learning. References to power are either made by stressing the (normative) feature of power sharing or in terms of a disciplined form of management power that is channeled through formal organizations and procedures (Folke et al. 2005). Some authors do acknowledge political conflict, but rather in the sense of open dispute and "bound conflict" of democratic competition that take a functional role in policy-oriented learning, analogous to the "invisible hand" of the market (Folke et al. 2005: 96). Furthermore, the AM literature does not systematically consider the potential implications of meso politics for the performance of AM arrangements and vice versa: the embedding of the members of an AM arena in overall actor constellations structured by fundamentally different interests and beliefs, not necessarily cooperative action orientations, as well as strategies that can be directed not only at collaborative problem solving, but also at capturing or instrumentalizing AM processes (cf. Kallis et al. 2009). The same is true for politics on a macro level. Adaptive management does not provide conceptual features for reflecting on overall societal conflicts and power structures of an incumbent political economy that, indeed, can affect the processes and substantial range of experimentation and learning within an AM arrangement (Folke et al. 2005: 641) and, thus, is reproduced and stabilized by AM (Nadasdy 2007).

Adaptive management concepts do refer extensively to the policy dimension of the framework. Adaptive management provides an elaborate understanding of problems based on a specific theoretical view of social-ecological systems as well as detailed conceptual means of science-like problem solving that emphasizes the significance of experimentation, knowledge acquisition, and learning. However, the reflection remains restricted to the micro level, covering policy-oriented activities within confined AM arrangements. Although governmental policies are referred to as overall context variables and enabling conditions for the emergence of AM (see Olsson et al. 2004), the interplay of both meso policies, such as existing regimes of land-use planning and environmental policy, and macro policies, such as overall policy ideas and paradigms, with the AM arrangement is not systematically considered.

In sum, AM prescribes a knowledge-oriented strategy of collaborative learning by doing within a governance arrangement that tends to remain conceptually restricted to the micro level of policy. Although some references are made to political institutions and policies on other levels, there are considerable reflective gaps first and foremost with regard to the politics on all three levels. Thus, AM appears as an approach that conceptually blocks out the nasty and dark sides of the political that may disturb rational problem solving. Neither are theoretical arguments provided to support the idea that AM arrangements do in fact work detached from politics; nor does AM put forward convincing design elements that can be assumed to actually safeguard the exclusion of politics in practice. The very effort of blocking out politics, however, renders AM itself a highly political concept as it tends to tacitly build on and reproduce given power relations.

\section{Transition Management}

Inspired by historically reconstructive research on sociotechnical transitions as well as the wideranging interdisciplinary field of innovation studies, complexity theory, and evolution theory (Geels 
2004, Elzen et al. 2004), TM represents a governance approach for shaping innovation processes and structural transitions within complex sociotechnical systems such as energy provision, mobility, and agriculture (Kemp et al. 2007a). There are various concepts of TM in place. However, we restrict our discussion to the concept of TM for sustainable development. Since TM was introduced by the Dutch government in the Fourth National Environmental Policy Plan (VROM 2001), we can observe a rapidly expanding practice and study of TM primarily within the Netherlands (Loorbach 2007, Smith and Kern 2009), which, more recently, are accompanied by critical accounts on the political and democratic implications of the concept (Hendriks and Grin 2007, Shove and Walker 2007, 2008, Rotmans and Kemp 2008, Hendriks 2009b, Meadowcroft 2009, Scrase and Smith 2009, Voß et al. 2009a).

\section{Assumptions, conceptualization, and operationalization}

Transition management builds on the idea of coevolutionary sociotechnical systems. Within these systems, structural transitions are assumed to evolve in a particular temporal pattern (as described by the so-called "S-curve") and in a multi-level context: Emerging as innovations in sociotechnical niches, they shift sociotechnical regimes and finally affect the broader sociotechnical landscape (Rotmans et al. 2001). Drawing on these theoretical assumptions about transitions, TM as a management concept is considered a deliberate approach to putting hands on the systems' inherent dynamics: to "influence the direction and speed of transitions by coordinating and enabling the processes that occur at different levels in a more systemic and evolutionary way" (Kemp and Loorbach 2006: 109). It aims at facilitating a more fundamental and long-term reflection on sociotechnical system dynamics in order to overcome the myopic orientation of established policy-making processes (Rotmans et al. 2007). However, TM is claimed to be fundamentally different from traditional political planning. Referring to the concept of "incremental politics," Kemp and Loorbach (2006: 109) define TM as an "attempt at goal-oriented modulation, not an attempt to achieve predefined outcomes through planning and control." Rotmans et al. (2007) situate TM more precisely in the middle ground between planning and incrementalism. Asserting that it combines the best of both worlds, they characterize $\mathrm{TM}$ as a "perspective incrementalism for sustainable development" (Rotmans et al. 2007: 25).
Overall, TM rests on a "softened rationality" that rejects the possibility of accurately steering sociotechnical systems from A to B, but assumes a chance to modulate $\mathrm{A}$ in the direction of $\mathrm{B}$.

As a "flexible and evolutionary approach, which will never become a blueprint" (Rotmans et al. 2007: 5), TM provides general principles such as systems thinking, long-term thinking, back-casting, and forecasting, a focus on learning by doing, an orientation toward system innovation and experimentation as well as participation that serve as starting points for practitioners and researchers to curtail problem-specific governance strategies (Kemp et al. 2007a, Rotmans et al. 2001). These principles come into play in a particular operational governance design that combines an institutional arrangement (transition arena) with various systemic transition instruments in a cyclical fourstep transition management process (Kemp and Loorbach 2006, Kemp et al. 2007a).

The first step refers to the creation of the transition arena, the institutional core of an emerging transition project. Its purpose is to facilitate interaction and learning, as well as set up a transition agenda in a network of relevant innovators and strategic thinkers from different backgrounds. The arena's participants-open-minded "visionaries" or "forerunners", who are "able to look beyond their own domain of working"-are selected according to the "transition problem at hand" and with respect to their competences (Kemp and Loorbach 2006: 112).

The second step is about "developing sustainability visions and transition agendas" within this arena. First, the arena's members are supposed to develop commonly shared perceptions of the transition problem(s) in a mode of multi-perspective and collective problem definition through which the participants will be informed by each other's perspectives and adjust their definitions of the problem accordingly (Kemp and Loorbach 2006: 113). Then, goals on two levels of abstraction are developed: although the "innovative and imaginative" transition vision serves as an overall long-term orientation, more specific transition images represent integral thematic targets that evolve over time according to collected "insights and learning effects" (Kemp and Loorbach 2006). Finally, transition pathways are set up to translate these strategic goals into operational means, taking into consideration expected developments such as trend 
breaks, behavioral and institutional changes, the uncertainties associated with the pathway as well as prospects for and barriers to implementation (Kemp and Loorbach 2006: 114). Ideally, some transition paths are pre-tested and explored in small-scale experiments that serve as further input for the overall transition program.

The third step of the TM cycle refers to "mobilizing actors and executing projects and experiments" through applicable transition programs that foster the "real use of new technologies in society" in order to learn from practice and facilitate processes of mutual adaptation (Kemp and Loorbach 2006: 115). To prevent backlashes, the transition project needs to create public support for the transition goals and related experiments. For this reason, the transition arena is supposed to constantly expand to less strategically oriented actors (such as local authorities) as well as the wider public.

According to the fourth step, the entire transition project is to be continuously evaluated and monitored by so-called "development rounds" that balance the achievement of interim objectives and assess the quality of the TM process. This constant evaluation is expected to induce learning processes, further the exploration of how sociotechnical systems function, and trigger the evolutionary selection of transition goals and pathways (Kemp and Loorbach 2006: 115).

\section{Transition management and politics}

Recent critical accounts have revealed a problematic relationship between TM and politics: a lack of conceptual awareness about the embedding of TM designs in political contexts on the one hand and an implicit normativity regarding the political on the other hand (Hendriks and Grin 2007, Shove and Walker 2007, Meadowcroft 2009). Notions such as the political process, political margins, the public, and political negotiations suggest that politics play a more distinct role in the TM literature than in AM. This is underscored by the consideration of TM as an effort to complement and transform policy making (Rotmans et al. 2001) and to work as a kind of a meta policy that integrates sectoral policies (Kemp et al. 2007a). Yet, TM's conceptual repertoire for reflecting on politics appears unspecified. Conceiving of the political process as a means by which society decides upon the overall transition goals (Kemp and Loorbach 2006: 109) implies that politics affect, and should affect, the transition project. But the political process appears to be restricted to the definition of goals, suggesting that all other steps of the TM cycle are (and should be?) disconnected from politics. Furthermore, it is unclear how exactly, and through which mechanisms, the political process is linked to the transition arena and how it relates to the goalsetting activities that take place within the arena (Meadowcroft 2009).

Kemp and Loorbach (2006: 109, Fig. 5.3) explicitly mention the existence of "political margins," implying that TM takes place in a broader political context. But neither the properties of these margins are elaborated nor is it specified where and how they actually play out. These political margins could be interpreted as being related to the public. However, the rather instrumental consideration of the "wider public" as a critical supportive factor for maintaining the TM process (Kemp and Loorbach 2006: 116) neglects the public's general interplay with the overall transition project. Other possible interpretations of political margins, such as trend breaks, behavioral and institutional changes, as well as barriers to and chances for implementation (Kemp and Loorbach 2006: 114), are presented as potential disruptions and triggers for particular substantial transition pathways only, without elaborating on how they may exert influence on the workings of the transition arena itself.

Occasionally, the TM literature points to the empirical significance of political negotiations dominated by power, interests, and conflicts within the transition arena that influence substantial efforts to shape sociotechnical change (Kemp and Loorbach 2006). There is also a clear awareness of the ambivalent and contested character of sustainability transitions (Kemp et al. 2007a). However, these concerns get lost when it comes to the articulation of governance designs where negotiations appear as merely cooperative and rational, yielding a common understanding and shared ideas, but no longer involving interest- and power-related strategic activities (cf. Meadowcroft 2009). Within the transition arena, "nasty politics" seem to vanish, power issues are channeled, and conflicts transformed into harmonious agreement.

How can this understanding of politics be characterized with respect to the framework sketched out above? Transition management provides overall design principles as well as concrete instruments for defining problems, 
creating visions, and setting up transition pathways. As such, it entails a differentiated conceptual repertoire for guiding policy-oriented reflections and actions with regard to the substantial modulation of sociotechnical transitions. Regarding polity, the approach considers the transition arena as the institutional core of a transition project. It also prescribes some functional features of this arena, such as the arena as a place for mutual learning. However, TM does not offer more specific ideas about which concrete institutional design elements might create the conditions for a transition arena to actually fulfill the functional expectations. This becomes particularly clear when it comes to politics. Although the possibility of political power struggles and conflicts, as well as the danger of transition projects being captured by partial interests are mentioned, there is hardly any reflection on how these forms of politics might affect the performance of a transition arena, on what institutional grounds they can be handled so that learning and experimentation within the transition arena can take place, or how they can be strategically used for facilitating social-technical change (cf. Berkhout et al. 2004).

With respect to the levels of political context, TM's conceptual focal point is on the micro level: on a confined transition arena that is expected to provide a protected breeding ground for new ideas and policy options. Certainly the transition arena is meant to span various levels and sectors of governance (Kemp et al. 2007a), and institutional changes are referred to as potential impact factors for substantial transition pathways (Kemp and Loorbach 2006). However, TM's conceptual apparatus barely addresses the implications of the meso and macro levels of polity and politics, such as overall constitutional structures or societal power relations for the working of and the performance of a transition arena itself. Likewise, the TM literature does explicitly consider links to a broader policy regime (meso policy) as TM is conceived as an effort to reach out to and transform, through the members of the transition network, innovation-related policy processes (Kemp et al. 2007b). Conversely, it does not take into account potential implications of incumbent policy regimes and the overall policy landscape for policy making within the transition arena.

In sum, TM highlights the policy dimension at a micro level, but does not systematically reflect on its interplay with other dimensions and levels of politics. Although TM clearly acknowledges that there is a world of politics, the relationship to this political context appears to be ambivalent. On the one hand, politics is assumed to be functionally significant for TM in various respects: by accounting for the definition of overall transition goals (political process), by restricting sociotechnical transitions (political margins), by serving as a supporting factor (public), and by imposing conflict (political negotiations). Moreover, TM's entire strategy is political as it is about establishing shadow arenas that are supposed to exert a transformative power on existing policy regimes. On the other hand, it seems that politics are excluded from the management of transitions by a conceptualization that places large parts of the political outside the realm of the transition arena, and by the promotion of an understanding of collaboration, experimentation, and learning that seems to ignore "nasty politics." Again, there is a conceptual gap in reflecting implications of TM as part of a political world that is not only affected by, but also affects TM. It remains unclear whether and on what grounds politics should and could actually be kept "outside" the transition arena and "switched off" while transition projects are set up and carried out.

\section{Comparative View of the Two Approaches}

The preceding discussion of AM and TM reveals various similarities. Similarities have also been noted by other authors searching for possibilities for cross-pollination (van der Brugge and van Raak 2007, Foxon et al. 2009) or a transfer of lessons (Smith and Stirling 2010). The latter, especially, highlight aspects of politics and how they can be integrated with a basic ontology of complex systems and their evolutionary dynamics that underlies both approaches. Both approaches suggest governance designs that take into account the limits to predictability and control due to the uncertainty and dynamics of complex systems. Addressing these challenges, they promote an experimental orientation, a learning-by-doing approach, as well as the participation and collaboration of diverse actors in order to integrate different perspectives and resources for governing. Table 2 provides a comparative overview of the two approaches.

Building on our analytical framework, we argue that AM and TM are also similar regarding their understanding of and reference to politics. The conceptual focus lies on policy at the micro level 
Table 2. Comparison of adaptive management and transition management

\begin{tabular}{|c|c|c|}
\hline & Adaptive Management & Transition Management \\
\hline $\begin{array}{l}\text { Theoretical } \\
\text { background }\end{array}$ & $\begin{array}{l}\text { Resource management, ecology, resilience } \\
\text { theory, "panarchy" theory }\end{array}$ & $\begin{array}{l}\text { Technology and innovation studies, complexity theory, } \\
\text { evolutionary theory }\end{array}$ \\
\hline $\begin{array}{l}\text { Realm of } \\
\text { application }\end{array}$ & $\begin{array}{l}\text { Socioecological systems (SES): functionally or } \\
\text { spatially defined systems (natural parks, river } \\
\text { basins, etc.) }\end{array}$ & $\begin{array}{l}\text { Sociotechnical systems (STS): arrangements providing } \\
\text { societal functions such as energy provision, agriculture, } \\
\text { transportation }\end{array}$ \\
\hline $\begin{array}{l}\text { Overall } \\
\text { objective }\end{array}$ & $\begin{array}{l}\text { Adaptation } \\
\text { Maintain resilience of socioecological systems } \\
\text { by increasing capacity to cope with complex } \\
\text { dynamics }\end{array}$ & $\begin{array}{l}\text { Change } \\
\text { Transform existing sociotechnical systems by modulating } \\
\text { ongoing innovation, leading to a sustainability transition }\end{array}$ \\
\hline $\begin{array}{l}\text { Basic } \\
\text { assumptions }\end{array}$ & $\begin{array}{l}\text { Complex and coevolving systems } \\
\text { Constant cyclic change is taking place } \\
\text { Universal cycle of collapse and renewal }\end{array}$ & $\begin{array}{l}\text { Complex and coevolving systems } \\
\text { Transitions are taking place } \\
\text { S-Curve as universal pattern of change }\end{array}$ \\
\hline $\begin{array}{l}\text { Concept of } \\
\text { governing }\end{array}$ & $\begin{array}{l}\text { Experimentation and learning } \\
\text { Navigate through cycles of social-ecological } \\
\text { change } \\
\text { Bring heterogeneous actors together to } \\
\text { construct and test policy hypotheses }\end{array}$ & $\begin{array}{l}\text { Experimentation and learning } \\
\text { Modulate sociotechnical dynamics (breed alternative } \\
\text { systems) } \\
\text { Provide platform for frontrunners to collectively } \\
\text { experiment and learn what works }\end{array}$ \\
\hline $\begin{array}{l}\text { Consideration } \\
\text { of politics }\end{array}$ & $\begin{array}{l}\text { Substitute politics by trust-based collaborative } \\
\text { learning in interaction with social-ecological } \\
\text { system, but no design elements for how to } \\
\text { achieve this } \\
\text { No systematic consideration of political } \\
\text { contexts }\end{array}$ & $\begin{array}{l}\text { Draw on institutionalized policy process for general } \\
\text { goals, but avoid interference. Negotiations in transition } \\
\text { arena without power and strategic interaction. Public } \\
\text { opinion as external factor } \\
\text { Add-on to "normal" policy making }\end{array}$ \\
\hline
\end{tabular}

(see Fig. 2). Micro politics, such as power struggles and tactical games by which actors try to impose their interests and views, gain dominance over resources and move into positions of authority within the respective arenas of experimentation and learning, however, they don't seem to play a role; neither do relations with actor constellations and power struggles in established domains of environmental policy, energy, construction, and transport to which AM and TM seek to contribute (meso politics); nor broader patterns of power and conflict within the particular political systems within which they are to work (macro politics). Although there are individual references in both literatures to broader policy and polity contexts, nowhere is there a systematic consideration of how the problem-solving approach of collaborative experimentation and learning could interfere with policy paradigms and institutional arrangements of established policy domains or with discourses on basic political beliefs and values or with constitutional frameworks of the political systems within which AM or TM are to be embedded (and that are often based on principles of representative democracy).

From the perspective of reflexive governance, AM and TM are indeed reflexive, as they place themselves within complex social-ecological and social-technical systems and acknowledge the limits of linear planning and control due to the inherent complexities and uncertainties of these systems. However, they do not consider the political conditions of governance. This is evident in the absence of detailed institutional provisions to actually safeguard reflexive governance designs from being dominated and captured by powerful political actors, as well as in a lack of distinct 
Fig. 2. Restricted view of politics in reflexive governance designs.

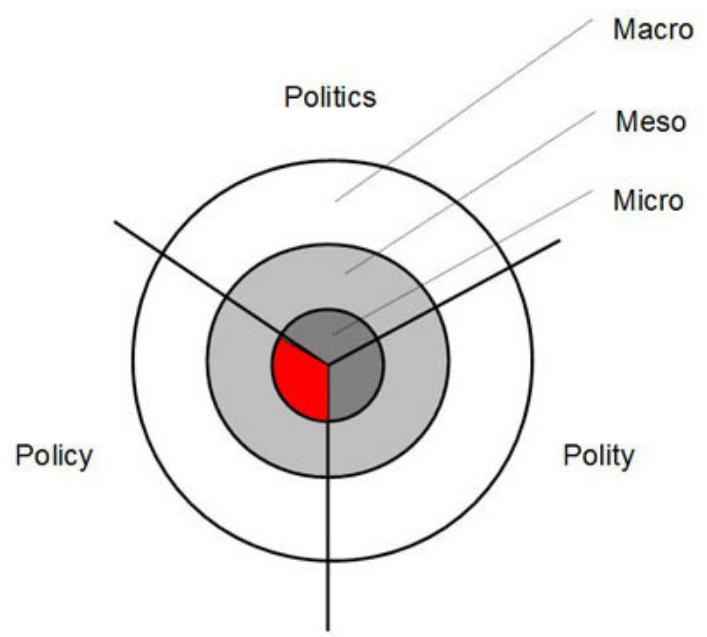

methods for reflecting on and dealing with "nasty politics" that may play out in envisioned processes of experimentation and learning.

In effect, $\mathrm{AM}$ and TM assume a space that is shielded against the influence of politics as we know it. They do not provide theoretical arguments for this assumption, however, or specific design elements that could be expected to constitute the conditions under which experimentation and collective learning can, in fact, operate independently of politics. Such a "depoliticized" view of governance may serve to attract policy makers as it suggests neutrality and carries a promise of problem-solving coalitions across established lines of political conflict (Smith and Kern 2009). However, it may be considered problematic for various reasons. Designs for social learning that do not adequately take into account conflict, power, and tactics are prone to domination and strategic instrumentalization by a powerful few who seek to further their own interests and positions rather than engaging in mutual learning for a sustainable society. Designs that do not consider their embedding in political contexts risk encountering a "problem of fit" with pre-existing patterns of politics and run the risk of being distorted as they are introduced for implementation. Finally, talking governance while veiling politics makes way for the rise of obscure and uncurbed forms of political power that lack legitimacy.

\section{INTEGRATING POLITICS IN THE DESIGN OF REFLEXIVE GOVERNANCE}

How can limitations in current conceptions of reflexive governance be overcome? Building on the analysis of governance designs for AM and TM in the preceding sections, we now turn to pathways for further developing those designs. This is also relevant for integrating politics in the discourse on reflexive governance more generally. Starting from a diagnosed focus of AM and TM on the policy dimension and at the micro level of politics, we discuss two directions for further research and development. These can be depicted as a horizontal and a vertical movement within the framework introduced above (see Fig. 3). The horizontal movement refers to the conceptual inclusion of conflict and power struggle within arrangements of collective learning (micro politics) and to the development of specific institutional settings that are required to make sure that asymmetries of power and attempts at dominating and instrumentalizing the learning process for particular interests are counterbalanced (micro polity). The vertical movement refers to a perspective on governance design that systematically considers interactions with existing patterns of governance on a level of policy domains and political systems. 
Fig. 3. Routes for integrating politics in reflexive governance designs.

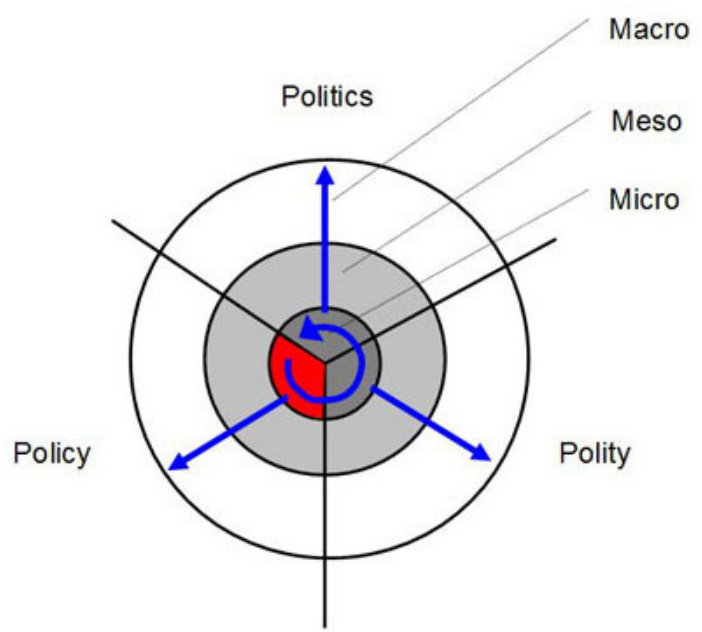

\section{Considering the Politics of Learning, Building Safeguards against Domination and Capture}

Both AM and TM build on an idealized image of cognitive learning that assumes unbiased observers of systemic changes, open-minded consideration of developmental options, and unequivocal interpretations of results from experimentation. Such a view neglects that experimental learning for sustainable development does not take place inside a scientific laboratory, somehow detached from immediate stakes and interests of actors, but in the real world where it is directly linked with ongoing processes of societal change (Groß et al. 2005, Rip 2006, Callon 2009). In a more or less direct way, experimenters with social-ecological or sociotechnical systems are themselves part of the experimental set up. Consequently, the framing, observation, and interpretation of sustainability experiments are highly reflexive exercises that affect identities, positions, and opportunities of individual actors. Whatever is being "learned" about sustainable development options in such arrangements has immediate implications for the possibility to continue certain lifestyles and business strategies or maintain positions of power, and thus entails high political stakes (Böschen and Weis 2007:169-171, Shove and Walker 2007: 766). Objectivistic models of scientific discovery (AM) or evolutionary selection (TM) appear problematic as they overlook the possibilities of strategic actors to shape or even to manipulate the set up and evaluation of experiments against the background of their own beliefs and interests (Meadowcroft 2009).

The literature on policy analysis and evaluation (Braybrooke and Lindblom 1963, Stone 1988, Guba and Lincoln 1989, Lindblom 1990, Fischer and Forester 1993), environmental policy making (Hajer 1995, Hisschemöller et al. 2001), and technology and risk assessment (Wynne 1975, 1995, Stirling 2003, 2006) provides ample evidence of how knowledge production and politics intertwine. For sustainable development, these issues intensify with the complexity of debated phenomena and the focus on transformative changes (Thompson 1997, Funtowicz et al. 1998, Voß et al. 2007).

Further development of designs for reflexive governance thus needs to take into account the politics of learning. A key task is to provide for safeguards against domination and instrumentalization by powerful groups. In the context of the framework set out above, this comes down to the integration of strategic interactions among conflicting societal perspectives (micro politics) and institutional provisions to calibrate and make political interactions productive (micro polity). Reflecting on adequate ways to work with conflict and power in the process of experimentation and learning is a necessary complement for coping with ambivalence, 
uncertainty, and distributed capacities in implementing sustainable development strategies. As conditions for deliberation and societal learning are controversially debated on a more fundamental level of social analysis and theory (Flyvbjerg 2001, Ryfe 2005, Parkinson 2006), we here identify a critical problem for the concept of reflexive governance more generally.

Without claiming originality or comprehensiveness, we wish to hint at three possible search strategies that could be followed in meeting the challenge of politics of learning:

- A first strategy would aim for the exclusion of politics in order to create conditions of social interaction following Habermas's concept of rational discourse (Habermas 1987, 1991). The goal would be to provide for reasoned arguments rather than interests, power, or any form of domination to bring about consensual problem definitions and solutions (Habermas 1987, 1991). Although such a strategy is implied in parts of the AM and TM literature, more thorough theoretical and conceptual work would be needed to devise specific procedural arrangements, rules for representative participation, and a certain cultural orientation of participants as institutional preconditions of a dominationfree discourse.

- A second strategy would not seek to overcome particular views and interests for a new shared understanding of complex systems, but rather would seek to make diverging perspectives on those systems explicit and reflect on the stakes that are involved in conceptualizing dynamics, pathways, and experiments. Such a strategy could find orientation in Schön and Rein's concept of "frame reflection" (Schön and Rein 1994). The goal would be to devise specific rules of procedure that enable participating actors to explain diverging understandings and conceptualizations of a given sustainability problem and reflect their particular views in relation to a diversity of others. Although this may not result in a unified strategy for dealing with socialecological or sociotechnical change, it draws attention to a diversity of perspectives and related interests that are relevant and need to be accommodated, even if they are rationally incommensurable. Also, the challenge here lies with developing procedural arrangements that guarantee inclusive participation, basic equality among participants, and open communication. As there is no underlying drive to conclude on a shared view, inducements and opportunities for actors to try and dominate the learning process are less pronounced than in the first strategy.

- A third strategy, finally, would not aim at transforming political struggle into some kind of cooperative reflection, but seek to use political interests and strategies as a resource for exploring pathways of sustainable development. It would aim to stimulate public controversies that are driven by attempts of various interested parties to promote their particular views. Social learning, in such an approach, would not require enlightened participants to transcend their political interests, but it would be a result of strategic mutual adaptation within a field of discursive forces. Actors may, perhaps slowly and often secretly, pick up certain elements of each other's perspectives if it helps them to defend a position and maintain public credibility (just as industry and conservative parties have come to adopt elements of environmentalists' perspectives). The search for governance designs according to this strategy could find inspiration in concepts such as "partisan mutual adjustment" (Lindblom 1959, 1965) or ideas related to "controversy as informal technology assessment" (Rip 1987). A specific challenge along this route is to devise arrangements that support a broad range of social perspectives, as well as those of marginalized groups, to be publicly articulated and to engage in a pluralistic political debate. Compared with the first two search strategies, this third one does not only relate to designs for governance arrangements focusing on particular issues of sustainable development, but also to a more general challenge of nurturing and maintaining a vital democracy.

This brief sketch of alternative search strategies suggests different ways by which the politics of learning could be integrated into the design of reflexive governance arrangements. They imply different concepts of learning that require specific directions for further conceptual work and practical 
experimentation with concrete designs. In any case, the crafting of detailed rules of procedure including methods of participant selection and process moderation is required to avoid domination and capture by powerful political interests. How this can be achieved may also be a question of particularities of the broader political context in which such designs are embedded.

\section{Embedding Governance Designs in Broader Political Contexts}

A second issue for further developing design strategies for reflexive governance relates to the embedding of new governance designs for societal learning within the context of already wellestablished patterns of politics, both on the levelspecific domains that are affected by the new design, and on the level of political systems as a whole. Neither AM nor TM are concerned with how such broader political contexts may affect the working or the acceptability of proposed designs or how designs might get distorted in the process of implementation as they meet with incumbent political forces. Adaptive management and TM are rather straightforwardly presented for universal application, even if advocates concede that some adaptation for specific contexts may be needed (Kemp and Loorbach 2006: 111). Meadowcroft characterizes TM as "hopelessly unrealistic" as it implies "substantial policy stability and resilient political coalitions to keep reform from being derailed by changes in political personnel and a turbulent conjuncture" (Meadowcroft 2005: 487). Kemp et al. (2007a: 89) admit that TM is "do-able in a society in which interests are well organized and steering from the top is basically impossible." Heiskanen et al. (2009) discuss substantial translations when transferred to other political contexts. Apparent problems with implementation are framed as "teething problems" (cf. Loorbach 2007: 282-285), not as an occasion to question the fit of new designs with established patterns of policy making (on this point see Smith and Kern (2009) and contributions in Voß et al. (2009b)).

A brief look at the literature of relevant policy studies provides ample evidence of established actor constellations and conflict patterns, policy paradigms, and political institutions conditioning the uptake and implementation of policy designs, both at the level of particular policy domains and political systems at large (e.g., Hall 1993, Pierson
1993, Sabatier and Jenkins-Smith 1993, Edmondson 1997, Olsen 1997, Baumgartner and Jones 2002). For governance designs that are based on experimentation and learning, it may be of special relevance that broader political contexts are also linked to specific epistemological cultures that define the kind of knowledge and procedures of knowledge production that are accepted to provide a relevant and valid basis for policy making (Hoppe and Petersen 1993, Hoppe 2005, Jasanoff 2005, Ryfe 2005, Hendriks and Grin 2007). Another specific challenge relates to interference with established policy discourses and practices (Kern and Howlett 2009, Smith and Kern 2009). With regard to obvious discrepancies between AM's and TM's concept of granting powers of defining sustainable development to a non-representative circle of participants with established institutions of representative democracy, some critics have accused advocates of these designs of following a vision of enlightened technocratic leadership while deliberately ignoring the conditions of democratic politics (Shove and Walker 2007, Avelino 2009, Hendriks 2009a). Against this background, it appears that robust design strategies require careful analysis of larger political system contexts and dynamics in order to anticipate interactions with reflexive governance arrangements.

For analyzing and anticipating political context dynamics, we can find some inspiration in AM and TM themselves, if we translate methods of system analysis from social-ecological and sociotechnical systems to political systems. Some tentative ideas are presented as starting points for further research and discussion:

- A first approach could be to undertake a systematic mapping of political contexts and their ongoing dynamics on various different levels in order to assess the political fit of new governance designs. Such mapping could build on our framework to systematically account for dimensions of policy, politics, and polity and contextual patterns at the micro, meso, and macro levels. For devising design strategies that incorporate interactions with political contexts it would be advisable to not only do a static mapping, but also undertake an analysis of ongoing dynamics of change in order to be able to anticipate (through different scenarios) opportunities and threats that are likely to arise in the future. 
- A second approach, which partly builds on the first one, could be a strategic adaptation of reflexive governance designs to create fit with current or upcoming openings in the political context. An obvious challenge would be to find a way to modify designs for reflexive governance (as derived from the analysis of complex dynamics of social, technological, and ecological systems) without losing their particular qualities (such as the acknowledgment of irresolvable ambivalences, fundamental uncertainty, and distributed power in shaping sustainable development). Adaptation to political contexts at the cost of losing important reflexive qualities would be as useless as insisting on fancy concepts of open-ended learning, which prove incapable of linking with existing political practices in any given context of application.

- Finally, as a third approach, one can think of actively engaging with political context dynamics with a view to influencing and shaping them. As designs for reflexive governance may imply practices that are radically new and different compared with established political practices in any particular context, broader political changes may indeed be a precondition for the introduction of reflexive governance. Based on the mapping of ongoing political dynamics as proposed above, such attempts could be focused on the advancement or creation of local openings within established patterns of governance. They could be provided by new issues that fall in between established problem-solving discourses and institutions or by specific cultural and institutional conditions within the confined setting of certain municipalities or policy domains. Such openings could provide niches for probing new governance designs and breeding alternative political practices. If experience with reflexive governance accumulates and new designs gain an institutional momentum of their own, local openings may become stretched and widened, and reflexive governance practices may start to interact with and shape broader political context developments.
In concluding this brief outlook on possible orientations for developing design strategies for reflexive governance, we suggest conceiving of the challenge of creating new forms of reflexive governance as an innovation process (Voß 2007a, b, Voß et al. 2009a). It may help in finding appropriate strategies if the development of new forms of governance is in itself seen as an openended search process, a challenge of navigating complex dynamic contexts and of coping with a lack of predictability and control. Rather than devising sophisticated learning models that correspond to some abstract theory of social-ecological or sociotechnical change, an innovation perspective on reflexive governance would be concerned with actual political practices and allowances and constraints of existing patterns of governing - and their dynamics. The development of reflexive governance designs would be a matter of probing and redesigning based on a critical evaluation of experiences - an ongoing process shaped by distributed activities of many involved actors, proponents as well as critics.

\section{CONCLUSIONS}

We set out to reflect on AM and TM, two particular designs of reflexive governance, from a broader perspective on politics. In order to identify blind spots in current discourses on reflexive governance and to work out strategies to overcome them, we have introduced a framework that distinguishes different dimensions (polity, policy, and politics) and levels of politics (micro, meso, macro). Our analysis shows that AM and TM build on a restricted conceptual view of politics. They are mainly concerned with the articulation of a strategy to cope with problems of social-ecological and sociotechnical complexity, namely a strategy of collaborative experimentation and learning. Against the background of our framework, both designs primarily deal with the policy dimension on a micro level. This leads to an idealistic concept of experimentation and learning as driven by a joint problem-solving interest of participating actors, as well as a disregard for "nasty politics" and detailed procedural provisions that can work as safeguards against domination and capture of learning processes by powerful actors. A further limitation is the neglect of interactions with the broader political context in which new designs are supposed 
to work. As alluded to in recent critical debates about both AM and TM, these shortcomings have the potential to severely reduce the viability of reflexive governance designs-in conceptual, practical, and normative regards.

This has led us to sketch two avenues of further research along which concepts and designs for reflexive governance could be revised with a view to integrating a broader view of political impacts on envisaged governance processes: a "horizontal" widening on the micro level of envisaged learning arrangements where the consideration of "nasty politics" requires safeguards against capture and instrumentalization. And a "vertical" widening to include the meso and macro levels of the political context as a starting point for the development of innovation strategies for new forms of governance.

Politics cannot be escaped or bypassed, nor eliminated or completely controlled by governance designs, but they can be analyzed and reflected on in order to devise more robust design strategies for new reflexive forms of governance. This is what we hope to encourage and support with the provision of this framework and sketching of avenues for further research.

Responses to this article can be read online at: http://www.ecologyandsociety.org/voll6/iss2/art9/responses/

\section{Acknowledgments:}

We are grateful for helpful comments on an earlier version of this paper from Adrian Smith and Johannes Stripple. Also, we thank Dzifa Ametowobla for editorial assistance and Per Olsson, Victor Galaz, and Adrian Smith for engaged and critical discussion from which the idea for this paper emerged. Jan-Peter Voß acknowledges funding through grant no. 01 UU0906 (Innovation in Governance Research Group) by the German Federal Ministry for Education and Research under its pogramme of Social-ecological Research.

\section{LITERATURE CITED}

Allan, C., and G. H. Stankey, editors. 2009. Adaptive environmental management. A practitioner's guide. Springer Science and Business Media B.V., Dordrecht, The Netherlands.

Armitage, D. 2008. Governance and the commons in a multi-level world. International Journal of the Commons 2(1):7-32.

Armitage, D., F. Berkes, and N. C. Doubleday, editors. 2007a. Adaptive co-management: collaboration, learning, and multi-level governance. University of British Columbia Press, Vancouver, British Columbia, Canada.

Armitage, D., F. Berkes, and N. C. Doubleday. 2007b: Introduction: Moving beyond comanagement. Pages 1-15 in D. Armitage, F. Berkes, and N. C. Doubleday, editors. Adaptive comanagement. Collaboration, learning, and multilevel governance. Columbia University Press, Vancouver, British Columbia, Canada.

Armitage, D., R. Plummer, F. Berkes, R. I. Arthur, A. T. Charles, I. J. Davidson-Hunt, A. P. Diduck, N. C. Doubleday, D. S. Johnson, M. Marschke, P. McConney, E. W. Pinkerton, and E. K. Wollenberg. 2009. Adaptive co-management for socialecological complexity. Frontiers in Ecology and the Environment 7(2):95-102.

Avelino, F. 2009. Empowerment and the challenge of applying transition management to ongoing projects. Policy Sciences 42(4):369-390.

Baumgartner, F. R., and B. D. Jones, editors. 2002. Policy dynamics. University of Chicago Press, Chicago, Illinois, USA.

Berkes, F., J. Colding, and C. Folke. 2003a. Introduction. Pages 1-29 in F. Berkes, J. Colding, and C. Folke, editors. Navigating social-ecological systems: building resilience for complexity and change. Cambridge University Press, Cambridge, UK.

Berkes, F., J. Colding, and C. Folke, editors. 2003b. Navigating social-ecological systems: building resilience for complexity and change. Cambridge University Press, Cambridge, UK. 
Berkes, F. 2007. Adaptive co-management and complexity: exploring the many faces of comanagement. Pages 19-37 in D. Armitage, F. Berkes, and N. C. Doubleday, editors. Adaptive comanagement. Collaboration, learning, and multilevel governance. Columbia University Press, Vancouver, British Columbia, Canada.

Berkhout, F., A. Smith, and A. Stirling. 2004. Sociotechnological regimes and transition contexts. In B. Elzen, F. W. Geels, and K. Green, editors. System innovation and the transition to sustainability. Theory, evidence, policy. Edward Elgar, Cheltenham, UK.

Böschen, S., and K. Weis. 2007. Die Gegenwart der Zukunft: Perspektiven zeitkritischer Wissenspolitik. VS Verlag für Sozialwissenschaften, Wiesbaden, Germany.

Braybrooke, D., and C. E. Lindblom. 1963. A strategy of decision: policy evaluation as a social process. Free Press, New York, New York, USA.

Brunner, R., T. A. Steelman, L. Coe-Juell, C. M. Cromley, C. M. Edwards, and D. W. Tucker. 2005. Adaptive governance. Integrating science, policy, and decision making. Columbia University Press, New York, New York, USA.

Callon, M. 2009. Civilizing markets: Carbon trading between in vitro and in vivo experiments. Accounting, Organizations and Society 34(34):535-548.

Conley, A., and M. A. Moote. 2003. Evaluating collaborative natural resource management. Society and Natural Resources 16:371-386.

Dietz, T., E. Ostrom, and P. C. Stern. 2003. The struggle to govern the commons. Science 302:19071912 .

Edmondson, R., editor. 1997. The political context of collective action. Power, argumentation and democracy. Routledge, London, UK.

Elzen, B., F. W. Geels, and K. Green, editors. 2004. System innovation and the transition to sustainability: theory, evidence and policy. Edward Elgar, Cheltenham, UK.

Fennell, D., R. Plummer, and M. Marschke. 2008. Is adaptive co-management ethical? Journal of Environmental Management 88(1):62-75.
Fischer, F., and J. Forester, editors. 1993. The argumentative turn in policy analysis and planning. Duke University Press, Durham, North Carolina, USA.

Flyvbjerg, B. 2001. Making social science matter: why social inquiry fails and how it can succeed again. Cambridge University Press, Cambridge, UK.

Folke, C. 2007. Social-ecological systems and adaptive governance of the commons. Ecological Research 22(1):4-15.

Folke, C., T. Hahn, P. Olsson, and J. Norberg. 2005. Adaptive governance of social-ecological systems. Annual Review of Environment and Resources 30 (1):441-473.

Folke, C., G. P. Kofinas, and F. S. Chapin, III, editors. 2009. Principles of ecosystem stewardship. Springer, New York, New York, USA.

Foxon, T. J., M. S. Reed, and L. C. Stringer. 2009. Governing long-term social-ecological change: what can the adaptive management and transition management approaches learn from each other? Environmental Policy and Governance 19(1):3-20.

Funtowicz, S., J. R. Ravetz, and M. O'Connor. 1998. Challenges in the use of science for sustainable development. International Journal of Sustainable Development 1(1):99-107.

Geels, F. W. 2002. Technological transitions as evolutionary reconfiguration processes: a multilevel perspective and a case-study. Research Policy 31(8-9):1257-1274.

Geels, F. W. 2004. Understanding system innovations: a critical literature review and a conceptual synthesis. Pages 19-47 in B. Elzen, F. W. Geels, and K. Green, editors. System innovation and the transition to sustainability: theory, evidence and policy. Edward Elgar, Cheltenham, UK.

Groß, M., H. Hoffmann-Riem, and W. Krohn. 2005. Realexperimente: ökologische Gestaltungsprozesse in der Wissensgesellschaft. Transcript, Bielefeld, Germany.

Guba, E., and Y. Lincoln. 1989. Fourth Generation Evaluation. Sage Publications, Newbury Park, California, USA. 
Gunderson, L. H., and C. S. Holling, editors. 2002. Panarchy: understanding transformations in human and natural systems. Island Press, Washington, D.C., USA.

Gunderson, L., and S. S. Light. 2006. Adaptive management and adaptive governance in the Everglades ecosystem. Policy Sciences 39(4):323334.

Habermas, J. 1987. Moralbewusstsein und kommunikatives Handeln. Suhrkamp, Frankfurt on Main, Germany.

Habermas, J. 1991. Erläuterungen zur Diskursethik. Suhrkamp, Frankfurt on Main, Germany.

Hahn, T., P. Olsson, C. Folke, and K. Johansson. 2006. Trust-building, knowledge generation and organizational innovations: the role of a bridging organization for adaptive comanagement of a wetland landscape around Kristianstad, Sweden. Human Ecology 34(4):573-592.

Hajer, M. A. 1995. The politics of environmental discourse: ecological modernization and the policy process. Oxford University Press, Oxford, UK.

Hall, P. A. 1993. Policy paradigms, social learning, and the state: the case of economic policymaking in Britain. Comparative Politics 25(3):275-296.

Heiskanen, E., S. Kivisaari, R. Lovio, and P. Mickwitz. 2009. Designed to travel? Transition management encounters environmental and innovation policy histories in Finland. Policy Sciences 42(4):409-427.

Hendriks, C. M. 2009a. Deliberative governance in the context of power. Policy and Society 28(3):173184.

Hendriks, C. M. 2009b. Policy design without democracy? Making democratic sense of transition management. Policy Sciences 42(4):341-368.

Hendriks, C. M., and J. Grin. 2007. Contextualising reflexive governance: the politics of Dutch transitions to sustainability. Journal of Environmental Policy and Planning 9(3/4):333-350.

Hisschemöller, M., R. Hoppe, W. N. Dunn, and J. R. Ravetz. 2001. Knowledge, power, and participation in environmental policy analysis: an introduction. Pages 1-28 in M. Hisschemöller, R.
Hoppe, W. N. Dunn, and J. R. Ravetz, editors. Knowledge, power, and participation in environmental policy analysis. Transaction Publishers, New Brunswick, New Jersey, USA.

Holling, C. S. 1978. Adaptive environmental assessment and management. Wiley, Chichester, UK.

Holling, C. S. 2001. Understanding the complexity of economic, ecological and social systems. Ecosystems 4(5):390-405.

Holling, C. S. 2003. Foreword: the backloop to sustainability. Pages $\mathrm{xv}-\mathrm{xxi}$ in $\mathrm{F}$. Berkes, J. Colding, and C. Folke, editors. Navigating socialecological systems: building resilience for complexity and change. Cambridge University Press, Cambridge, UK.

Hoppe, R. 2005. Rethinking the science-policy nexus: from knowledge utilization and science technology studies to types of boundary arrangements. Poiesis and Praxis: International Journal of Technology Assessment and Ethics of Science 3(3):199-215.

Hoppe, R., and A. Petersen. 1993. Handling frozen fire: political culture and risk management. Westview Press, Boulder, Colorado, USA.

Howlett, M. 2009. Governance modes, policy regimes and operational plans: a multi-level nested model of policy instrument choice and policy design. Policy Sciences 42(1):73-89.

Jasanoff, S. 2005. Designs on nature: science and democracy in Europe and the United States. Princeton University Press, Princeton, New Jersey, USA.

Kallis, G., M. Kiparsky, and R. Norgaard. 2009. Collaborative governance and adaptive management: lessons from California's CALFED Water Program. Environmental Science and Policy 12(6):631-643.

Kato, S., and Ahern, J. 2008. Learning by doing: adaptive planning as a strategy to address uncertainty in planning. Journal of Environmental Planning and Management 51(4):543-559.

Kemp, R. 1994. Technology and the transition to environmental sustainability: the problem of technological regime shifts. Futures 26:1023-1046. 
Kemp, R., and D. Loorbach. 2006. Transition management: a reflexive governance approach. Pages 103-130 in J.-P. Voß, D. Bauknecht, and R. Kemp, editors. Reflexive governance for sustainable development. Edward Elgar, Cheltenham, UK.

Kemp, R., D. Loorbach, and J. Rotmans. 2007a. Transition management as a model for managing processes of co-evolution towards sustainable development. International Journal of Sustainable Development and World Ecology 14(1):78-91.

Kemp, R., J. Rotmans, and D. Loorbach. 2007b. Assessing the Dutch energy transition policy: how does it deal with dilemmas of managing transitions? Journal of Environmental Policy and Planning 9 (3/4):315-331.

Kenny, M., and J. Meadowcroft, editors. 1999. Planning sustainability. Routledge, London, UK.

Kern, F., and M. Howlett. 2009. Implementing transition management as policy reforms: a case study of the Dutch energy sector. Policy Sciences 42(4):391-408.

Kern, F., and A. Smith. 2008. Restructuring energy systems for sustainability? Energy transition policy in the Netherlands. Energy Policy 36:4093-4103.

Kiser, L.L., and E. Ostrom. 1982. The three worlds of action. A metatheoretical synthesis of institutional appraoches. Pages 179-222 in E. Ostrom, editor. Strategies of political inquiry. Sage, Beverly Hills, California, USA.

Kofinas, G. P. 2009. Adaptive co-management in social-ecological governance. Pages 77-101 in C. Folke, G. P. Kofinas, and F. S. Chapin, III, editors. Principles of ecosystem stewardship. Springer, New York, New York, USA.

Lafferty, W. M., editor. 2004. Governance for sustainable development: the challenge of adapting form to function. Edward Elgar, Cheltenham, UK.

Leach, M., G. Bloom, A. Ely, P. Nightingale, I. Scoones, E. Shah, and A. Smith. 2007. Understanding governance: pathways to sustainability. STEPS Working Paper 2. STEPS Centre (Social, Technological and Environmental Pathways to Sustainability), Brighton, UK. [online] URL: http:/ /www.steps-centre.org/PDFs/final steps governance. pdf.
Lebel, L, J. M. Anderies, B. Campbell, C. Folke, S. Hatfield-Dodds, T. P. Hughes, and J. Wilson. 2006. Governance and the capacity to manage resilience in regional social-ecological systems. Ecology and Society 11(1): 19. [online] URL: http://www.ecolog yandsociety.org/vol11/iss1/art19/.

Lee, K. N. 1993. Compass and gyroscope. Integrating science and politics for the environment. Island Press, Washington, D.C., USA

Lee, K. N. 1999. Appraising adaptive management. Conservation Ecology 3(2): 3. [online] URL: http:/ /www.ecologyandsociety.org/vol3/iss2/art3/.

Lindblom, C. E. 1959. The science of "muddling through." Public Administration Review 19(2):7988.

Lindblom, C. E. 1965. The intelligence of democracy. Free Press, New York, New York, USA.

Lindblom, C. E. 1990. Inquiry and change. The troubled attempt to understand and shape society. Yale University Press, New Haven, Connecticut, USA.

Loorbach, D. 2007. Transition management: new mode of governance for sustainable development. International Books, Utrecht, The Netherlands.

McLain, R. J., and R. G. Lee. 1996. Adaptive management: promises and pitfalls. Environmental Management 20(4):437-448.

Meadowcroft, J. 2005. Environmental political economy, technological transitions and the state. New Political Economy 10(4):479-498.

Meadowcroft, J. 2009. What about the politics? Sustainable development, transition management, and long term energy transitions. Policy Sciences 42(4):323-340.

Nadasdy, P. 2003. Hunters and bureaucrats. Power, knowledge, and Aboriginal-state relations in the southwest Yukon. University of British Columbia Press, Vancouver, British Columbia, Canada.

Nadasdy, P. 2007. Adaptive co-management and the gospel of resilience. Pages 208-227 in D. Armitage, F. Berkes, and N. C. Doubleday, editors. Adaptive co-management. Collaboration, learning, 
and multi-level governance. University of British Columbia Press, Vancouver, British Columbia, Canada.

Norton, B. G. 1999. Pragmatism, adaptive management, and sustainability. Environmental Values 8(4):451-466.

Norton, B. G. 2005. Sustainability. A philosophy of adaptive ecosystem management. University of Chicago Press, Chicago, Illinois, USA.

Olsen, J. P. 1997. Instutional design in democratic contexts. The Journal of Political Philosophy 5 (3):203-229.

Olsson, P., C. Folke, and F. Berkes. 2004. Adaptive comanagement for building resilience in socialecological systems. Environmental Management 34 (1):75-90.

Olsson, P., L. H. Gunderson, S. R. Carpenter, P. Ryan, L. Lebel, C. Folke, and C. S. Holling. 2006. Shooting the rapids: navigating transitions to adaptive governance of social-ecological systems. Ecology and Society 11(1): 18. [online] URL: http: //www.ecologyandsociety.org/vol11/iss1/art18/.

Parkinson, J. 2006. Deliberating in the real world: problems of legitimacy in deliberative democracy. Oxford University Press, Oxford, UK.

Pierson, P. 1993. When effect becomes cause: policy feedback and political change. World Politics 45:595-628.

Plummer, R. 2009. The adaptive co-management process: an initial synthesis of representative models and influential variables. Ecology and Society 14(2): 24. [online] URL: http://www.ecolog yandsociety.org/vol14/iss2/art24/.

Plummer, R., and J. FitzGibbon. 2007. Connecting adaptive co-management, social-learning, and social capital through theory and practice. Pages 3861 in D. Armitage, F. Berkes, and N. C. Doubleday, editors. Adaptive co-management. Collaboration, learning, and multi-level governance. University of British Columbia Press, Vancouver, British Columbia, Canada.

Rein, M., and D. Schön. 1993. Reframing policy discourse. Pages 145-169 in F. Fischer, and J. Forester, editors. The argumentative turn in policy analysis and planning. Duke University Press, Durham, North Carolina, USA.

Rip, A. 1987. Controversies as informal technology assessment. Knowledge: Creation, Diffusion, Utilization 8(2):349-371.

Rip, A. 2006. A co-evolutionary approach to reflexive governance-and its ironies. Pages 82 100 in J.-P. Voß, D. Bauknecht, and R. Kemp, editors. Reflexive governance for sustainable development. Edward Elgar, Cheltenham, UK.

Rotmans, J., and R. Kemp. 2008. Detour ahead: a response to Shove and Walker about the perilous road of transition management. Letters to the editor. Environment and Planning A 40(4):1006-1012.

Rotmans, J., R. Kemp, and M. von Asselt. 2001. More evolution than revolution: transition management in public policy. Foresight 3(1):1531.

Rotmans, J., D. Loorbach, and R. Kemp. 2007. Transition management: its origin, evolution and critique. Workshop on Politics and governance in sustainable socio-technical transitions, 19-21 September2007. Berlin, Germany.

Ryfe, D. M. 2005. Does deliberative democracy work? Annual Review of Political Science 8(1):4971.

Sabatier, P. A., and H. C. Jenkins-Smith, editors. 1993. Policy change and learning: an advocacy coalition approach. Westview Press, Boulder, Colorado, USA.

Schneider, A., and H. Ingram. 1993. Social construction of target populations: implications for politics and policy. American Political Science Review 87(2):334-347.

Schön, D., and M. Rein. 1994. Frame reflection: toward the resolution of intractable policy controversies. BasicBooks, New York, New York, USA.

Scrase, I., and A. Smith. 2009. The (non-)politics of managing low carbon socio-technical transitions. Environmental Politics 18(5):707-726.

Sendzimir, J., P. Magnuszewski, P. Balogh, and A. Vári. 2006. Adaptive management to restore 
ecological and economic resilience in the Tisza river basin. Pages 131-161 in J.-P. Voß, D. Bauknecht, and R. Kemp, editors. Reflexive governance for sustainable development. Edward Elgar, Cheltenham, UK.

Shilling, F. M., J. K. London, and R. S. Liévanos. 2009. Marginalization by collaboration: environmental justice as a third party in and beyond CALFED. Environmental Science and Policy 12(6):694-709.

Shove, E., and G. Walker. 2007. CAUTION! Transitions ahead: politics, practice, and sustainable transition management. Environment and Planning A 39:763-770.

Shove, E., and G. Walker. 2008. Transition management and the politics of shape shifting. Letters to the Editor. Environment and Planning $A$ 40(4):1012-1014.

Smith, A., and F. Kern. 2009. The transitions storyline in Dutch environmental policy. Environmental Politics 18(1):78-98.

Smith, A., and A. Stirling. 2007. Moving outside or inside? Objectification and reflexivity in the governance of socio-technical systems. Journal of Environmental Policy and Planning 9(3/4):351373.

Smith, A., and A. Stirling. 2010. The politics of social-ecological resilience and sustainable sociotechnical transitions. Ecology and Society, 15(1): 11. [online] URL: http://www.ecologyandsociety.org/ vol15/iss 1/art11/.

Stirling, A. 2003. Risk, uncertainty and precaution: some instrumental implications from the social sciences. Pages 33-76 in F. Berkhout, M. Leach, and I. Scoones, editors. Negotiating environmental change: new perspectives from social science. Edward Elgar, Cheltenham, UK.

Stirling, A. 2006. Precaution, foresight and sustainability. Pages 225-272 in J.-P. Voß, D. Bauknecht, and R. Kemp, editors. Reflexive governance for sustainable development. Edward Elgar, Cheltenham, UK.

Stone, D. A. 1988. Policy paradox and political reason. Harper Collins, New York, New York, USA.
Thompson, M. 1997. Cultural theory and integrated assessment. Environmental Modelling and Assessment 2:139-150.

van der Brugge, R., and R. van Raak. 2007. Facing the adaptive management challenge: insights from transition management. Ecology and Society 12(2): 33. [online] URL: http://www.ecologyandsociety.org/ vol12/iss2/art33/.

von Prittwitz, V. 1994. Politikanalyse. Leske and Budrich, Opladen, Germany.

Voß, J.-P. 2007a. Designs on governance. Development of policy instruments and dynamics in governance. Dissertation. Twente University, Enschede, The Netherlands. [online] URL: http://d oc.utwente.nl/58085/.

Voß, J.-P. 2007b. Innovation processes in governance. The development of emissions trading as a new policy instrument. Science and Public Policy 34(5):329-343 [online] URL: http://docserv er.ingentaconnect.com/deliver/connect/beech/03023427/ v34n5/s3.pdf?expires $=1304978906 \&$ id $=62664149$ \& titleid $=898 \&$ accname $=$ Guest + User $\&$ checksum $=0$ AF5C195E643581063A60EEAB2682522.

Voß, J.-P., D. Bauknecht, and R. Kemp, editors. 2006. Reflexive governance for sustainable development. Edward Elgar, Cheltenham, UK.

Voß, J. , and R. Kemp. 2006. Sustainability and reflexive governance: introduction. Pages 3-28 in J.-P. Voß, D. Bauknecht, and R. Kemp, editors. Reflexive governance for sustainable development. Edward Elgar, Cheltenham, UK.

Voß, J.-P., J. Newig, B. Kastens, J. Monstadt, and B. Nölting. 2007. Steering for sustainable development: a typology of problems and strategies with respect to ambivalence, uncertainty and distributed power. Journal of Environmental Policy and Planning 9(3/4):193-212.

Voß, J., A. Smith, and J. Grin. 2009a. Designing long-term policy: rethinking transition management. Policy Sciences 42(4):275-302. DOI: 10.1007/ s11077-009-9103-5

Voß, J., A. Smith, and J. Grin. 2009b. Designing long-term policy. Special issue. Policy Sciences 42 (4). [online] URL: http://www.springerlink.com/co ntent/0032-2687/42/4/. 
VROM (Ministy of Housing, Spatial Planning and the Environment). 2001. Where there is a will there is a world: working towards sustainability. Fourth national environmental policy plan. VROM, The Hague, The Netherlands.

Walters, C. J. 1986. Adaptive management of renewable resources. Macmillan, New York, New York, USA.

Walters, C. J. 1997. Challenges in adaptive management of riparian and coastal ecosystems. Conservation Ecology 1(2): 1. [online] URL: http:/ /www.consecol.org/vol1/iss2/art1/.

Walters, C. J. 2007. Is adaptive management helping to solve fisheries problems? Ambio 36 (4):304-307.

Wynne, B. 1975. The rhetoric of consensus politics: a critical review of technology assessment. Research Policy 4(2):108-158.

Wynne, B. 1995. Technology assessment and reflexive social learning: observations from the risk field. Pages 19-36 in A. Rip, T. J. Misa, and J. P. Schot, editors. Managing technology in society: the approach of constructive technology assessment. Pinter, London, UK. 